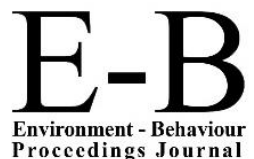

Environment - Behaviour
Procecdings Journal

\section{CSSR 2018}

https://cssr.uitm.edu.my/2018/

5th International Conference on Science and Social Research Le Meridien Kota Kinabalu Hotel, 5 - 6 December 2018

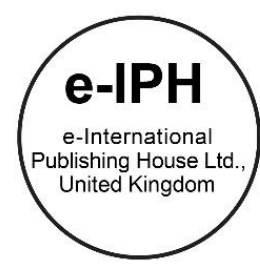

\title{
The Politic of Health Communication Model to ImproveGovernment Hospital Service
}

\author{
Umaimah Wahid \\ Universitas Budi Luhur, Cileduk Raya Street, North Petukangan, South Jakarta, Indonesia 12260 \\ umaimah.wahid@budiluhur.ac.id
}

\begin{abstract}
The report aims to investigate poor health services among patients, doctors, medical personnel, non-transparent health information, and unequal health access for the community due to social, political, and economic status. The research used qualitative descriptive methods. The result explained that serious efforts are required to improve health services to the public in hospitals, good relations between doctors, media personnel, and patients. Health communication must be applied to develop good relationships between hospitals, doctors, and patients. Aceh government requires to make a political policy that guarantees the quality of health services equitably and equally. The community has the right to have access to health easily, equitably, and transparently.
\end{abstract}

Keywords: politic-health communication, model, hospital-government

eISSN: 2398-4287@ 2020. The Authors. Published for AMER ABRA cE-Bsby e-International Publishing House, Ltd., UK. This is an open access article under the CC BYNC-ND license (http://creativecommons.org/licenses/by-nc-nd/4.0). Peer-review under responsibility of AMER (Association of Malaysian Environment-Behaviour Researchers), ABRA (Association of Behavioural Researchers on Asians) and CE-Bs (Centre for Environment-Behaviour Studies), Faculty of Architecture, Planning \& Surveying, Universiti Teknologi MARA, Malaysia.

DOI: https://doi.org/10.21834/ebpj.v5iSI3.2563

\subsection{Introduction}

People in any country need satisfying and affordable health services. The level of performing health services is a measure of the welfare and happiness of people. However, satisfying, cheap and equitable health services for all levels of society are quite difficult to fulfil. In Indonesia, the problem of health services is also inadequate, equitable and can be reached by every member of society. Several reasons why health services are still below standard in Indonesia are 1) connectivity, 2) clarity of regulation, 3) demography, 4) archipelago, 5) low services and 6) feasible use of technology. Many people do not have the right to health properly in reality. The accessibility of health is still extensively shared by those people who have a lot of money or power. One of the provinces considered to be inferior in providing services to the community is the Province of Aceh. As nowadays, Aceh province has already had Aceh Health Network that automatically migrates the implementation and its use with Social Security Administrator for Health (Badan Penyelenggara Jaminan Sosial-BPJS). Nevertheless, the more crucial matter is the poor health care experienced by the community. Health services still probe at the status of the patients.

Poor health services in Aceh have become common knowledge, even the Ombudsman as an institution that oversees the quality of public service asserted that the quality of health services in Aceh is still in the 'very bad' category. Indonesian Public Service Supervisory Agency, Ombudsman in 2016 declared that health services in Aceh were very bad. Some cases happen in Aceh such as 1) doctors rarely come or are not in a hospital/public health centre, 2) slow response of hospital personnel, 3) malnutrition cases in

eISSN: 2398-4287@ 2020. The Authors. Published for AMER ABRA cE-Bsby e-International Publishing House, Ltd., UK. This is an open access article under the CC BYNC-ND license (http://creativecommons.org/licenses/by-nc-nd/4.0/). Peer-review under responsibility of AMER (Association of Malaysian Environment-Behaviour Researchers), ABRA (Association of Behavioural Researchers on Asians) and cE-Bs (Centre for Environment-Behaviour Studies), Faculty of Architecture, Planning \& Surveying, Universiti Teknologi MARA, Malaysia. DOI: https://doi.org/10.21834/ebpj.v5iSI3.2563 
Aceh (16 cases in 2017), 4) Four female patients experiencing harassment in Zainal Abidin regional Hospital (RSUZA) Banda Aceh, (5) the death of mothers and babies due to ignorance of the doctors at Zainal Abidin Regional Hospital (RSUDZA) and other hospitals, (6) rejection of referral patients using Social Insurance Administration Organization (BPJS) and (7) service differences due to social and economic status (unequal). Therefore, society has not been satisfied with health services. https://www.ajnn.net/news/banyakmasalah-ombudsman-kaji-pelayanan-kesehatan-di-aceh-barat/index.html.

Those various problems and services phenomena are evidence of a lack of inadequate opportunity and health community quality in the wide community. Service excellence should be the consideration of crucial features in the health sector. The obligation of the state ought to guarantee public health as the right of every citizen. The state or authority cannot ignore the complicated matter of public health. It is because health determines the quality of life of people and has implications for their products daily. Health is becoming a must-have for the community or citizens.

The government requires to improve the quality of health services as a manifestation that the government is eager to improve the quality of life of the people. The Aceh government must ensure that all communities have equal rights in health services. It needs to be guaranteed because some of the poor do not have the same opportunity to receive adequate health services as the rich. The accessibility of health is still extensively shared by those people who have a lot of money or power. In the health sector, especially in Banda Aceh Zainal Abidin Hospital, several cases concern the people of Aceh and even the nation. Some incidents are inappropriate and experienced by people who seek treatment. However, the government is obliged to provide the best and most outstanding services to the community, but until now, government hospitals are still poor in Aceh. Aceh Province not only has Social Security Administrator for Health but also has Health Network. Health facilities and the number of patients are not balanced. Rules are sometimes too complicated and overlapping, which makes health problems chaotic.

Unintentionally, the hospital health system is required to expel poor patients who cannot fulfil administrative procedures and all the trivial matters. As if to say: Poor people can not be sick. But if the patient has power and money, accessible methods are available and even receive special care. The important role of health communication as explained in the research of Annegret Hannawa, professor of communication at the University of Lugano, Switzerland, shows that nearly 98,000 patients die each year due to preventable medical errors (p. 33). Hannawa also writes that although this is a legal obligation, most doctors fail to disclose this error or reveal it in an incompetent way, producing dangerous results, when doctors, patients, and hospital employees often ignore this error. (Carmack, 2010). The service condition at the largest Government Hospital in Banda Aceh is also very concerning. Many patients do not get proper services simply because of their economic condition and background. According to Mirza Putra, chairman of the public health advocacy commission), Mirtza Putra admitted that health services in Aceh are still low. "The breast cancer patient's family has recently complained to the public health chief for the services they get at Zainal Abidin Hospital "Patients have been back and forth Lhoksumawe - Banda Aceh, but until now there is no certainty about scheduled operations that will be executed". Patients in surgery suffered heavy bleeding after surgery so it must be treated in ICCU for 12 hours. Health development is carried out by giving priority to the public interest rather than the interests of individuals or groups. Quality health efforts are carried out by utilizing the development of science and technology and must prioritize the approaches to improve health and prevent disease. Aceh is the first province in Indonesia to provide health insurance for its population. The program was successful, 24 billion rupiahs have been provided by the Aceh government through the 2010 Aceh revenue expenditure budget. Around 1.2 million Aceh residents from all levels will have free health facilities. Even though the JKA (Aceh Health Insurance) Program is already considered a solution, there are still problems. For example, the lack of medicines, the poor service of health workers, and the lack of socialization to the wider society (Satria, Widarti dan Anwar, 2016).

One of the causes of poor service to the community is the bad quality of communication. Good and effective communication will be able to create models, systems, and behaviours in public health services. It starts from health communication strategies, process, activity, message packaging, media utilization, spoken person and community independence to express their grievance or experience that is not appropriate that they experienced. Good health communication will generate satisfaction in society because it will create the independence and quality of dialogue between both parties. Therefore, health communication is needed to improve health services by the government. Management of health services aims to improve the governance of the service system to provide optimal services. An integrated service system can be respected if all components have equal services regardless of their background. Based on the background that has been explained, the formulations of the problem that became the focus of research are: (1) Why is health communication in health services so necessary to improve health services to the community? (2) What is the communication model of government hospital health services in Aceh to improve service quality?

\subsection{Literature Review}

\subsection{Health Communication-Politic}

Social conditions and government policies are required to improve public services in the health sector. The government must be able to guarantee that they have political authority to determine their attitude and create policies and to ensure that the policies are implemented properly, whatever the challenges that arise. Public health professionals should understand the political dimensions of the problem and proposed solutions, whether they hold positions in government, advocacy groups, research organizations, or the health care industry. This understanding can help leaders to anticipate better both short-term constraints and long-term opportunities for change. 
A good policy does not guarantee the quality of health increases but instead requires synergy with various stakeholders involved in health services. One strategy that can maximize energy systems, programs and implementation as a form of policy is communication. Communication has a major role in public health and encourages health professionals around the world to utilize communication skills whenever possible. Health researchers and practitioners agree that health communication is an approach that refers to various scientific disciplines, including mass communication, social marketing, health education, anthropology, and sociology (Bernhardt, 2004; Institute of Medicine, 2003; World Health Organization, 2003; Schiavo, 2007).

Health communication, as an area of study has always focused on the real world and communication in everyday life (Atkin \& Marshall, 1996). In American universities, it grew two different areas of study: interpersonal interaction, where researchers became interested in the communication between doctors and patients, and mass communication, where researchers began to use the media to promote public health campaigns (Kreps, Bonaguro \& Query, 1998; Thompson, 2006; Lederman, Kreps, and Roberto, 2017). Deddy Mulyana explains the importance of health communication for professionals in the medical world, and the way of communication has an impact on patients and the general public. Various aspects of culture (life view, religion, community norms, language, body language, psychological condition and others) affect the interaction of medical professionals with patients and society. One important aspect is the health communication perspective. The book also reveals studies on how medical professionals communicate with patients and the general public with diverse cultural backgrounds. This becomes more value especially to meet the free market in the wider future as a globalization trend (Mulyana, 2016).

Communication is the process of delivering a message by the communicator to the communicant (Berlo, 1960). The concept of communication comes from Latin, which means participating or giving information; it can also be derived from the word communist , which means common property. (Komala, Hafiar, Damayanti, Puspitasari, 2014). The importance of health communication for medical professionals who consider various aspects of culture (Mulyana, 2016), about health communication such as 1) Errors in health communication can be fatal for the continuity of the health industry, especially for hospitals, doctors and medical professionals. 2) Poor communication can damage patient/community trust in health institutions. Health communication is the process of delivering messages that contain matters relating to health by the sender of the message to the audience through various media that are considered appropriate. The process of delivering health messages by communicators through traditional channels, mass media, news media, and social media, and 3) Health communication can encourage to improve health services and fulfil the rights of patients.

The approach taken by The Ghana Health Service is the WHO DOTS method. DOTS stands for Directly Observed Treatment, a short course and consists of five different components designed to help and prevent TB (WHA, 2016). The five components are as follows 1) Political commitment with continuous improvement, 2) Detection of cases through bacteriology that is guaranteed quality, 3) Standard care with patient supervision and support, 4) Effective drug supply and management systems, and 5) Monitoring an impact evaluation and measurement system (WHO, 2010 in Prilutski, 2010). Political strength is required to develop the quality of health services for the community. The development effort requires involving government actions, whether in treatment, disease prevention or health promotion. The involvement of the government is usually able to produce a stronger and more widespread impact, and that is difficult to do by individuals. According to Gostin, the political community makes it easy to build networks, organize cooperation, share bonds between members: organized society to protect people from service and treatment in the health sector. Public health can only be achieved through collective action, not through individual efforts (Oliver, 2006).

\subsection{Health Communication Components}

Communication is a long-term process. Influencing people and their behaviour requires an ongoing commitment to health problems and their solutions. It is rooted in a deep understanding of the target audience and their environment and aims to build consensus among audiences about potential action plans. Health communication programs change or evolve from what was originally designed by communication experts because of input and participation from key opinion leaders, patient groups, professional associations, policymakers, audience members, and other key stakeholders.

In health communication, educating the target audience about health issues and how to deal with them is only the first step of a long-term audience-centred process. This process often requires theoretical flexibility to accommodate the needs of interested groups and audiences. The best communication strategy for developing countries is based on the idea of integration with society. The principles of inclusion, participation, and self-determination help to defeat the main problems perceived by only increase understanding of why certain health behaviours are wrong (Ford, Abimbola, Renshaw \& Nkum, 2005). Such problems by only increasing understanding include the fact that simply understanding a problem does not lead to a change in behaviour and that awareness does not make people responsible for their health. Health communication with patients include information relating to individual health conditions, information about how to maximize treatment and how to provide therapy. Health communication in patients/sufferers is more therapeutic, which means that it facilitates the healing process. The health communication component is: (Rakhmat, 2004).

1.A communicator is a person or institution that conveys a message. Messages are statements supported by symbols that have meaning, for example, the bias in the form of slogans about healthy living and others.

2. Communicant is the people who receive messages. The communicant bias is in the form of a particular community or institution that is responsible for improving the health status of the community.

3. Media is a means or channel that supports the process of delivering messages. Media referred to bias in the form of print and electronic media which used to be done with extension activities. 
4. Effects are the effects of messages. Effect/impact is the value of achievement in sending messages. Good and vice versa depends on how a communicator delivers the message.

5. The response is a response or a set of reactions to the communicator after the message.

6. Feedback is the response of communicants when delivering a message to the communicator.

7. Interactive is two-way communication, is mutual action, mutual active and interconnected, and has a reciprocal process (Warsawa, 2018).

\subsection{Methodology}

The research method uses descriptive qualitative. Bogdan and Taylor in Moleong (2010: 4) suggest that qualitative research is a research procedure that produces descriptive data in the form of written or oral words from people and observable behaviour. Qualitative description (QD) is a label used in qualitative research for studies that are descriptive in nature, particularly for examining health care and nursing-related phenomena (Polit \& Beck, 2009, 2014 in Kim, Sefcik, and Bradway, 2018). Sugiyono (2015) argues that the descriptive analytical method is a method that aims to describe or give a picture of a research object that is examined through the sample or data that has been collected and make conclusions that are generally accepted. Research on political-health communication focuses on the object of the need for the authority of the Aceh regional government to improve health services in government hospitals to patients by designing health communication strategies because the government has the power and authority to improve service quality. The research subjects are policymakers in the field of health services, health observers, hospitals, doctors, and patients.

Some questions that arise are: 1) What is their opinion about health services in Aceh, especially in government hospitals? 2) What is their assessment of the quality of health communication in health services, are they satisfied or not? 3) Is the political policy needed to improve the quality of health services? And 4) What kind of health communication model is needed in the development of health communication, does the community need to be involved? Data collection techniques used were observation on online sources about the problem of health services in government hospitals in Aceh and interviews with people who use health services. Various problems arise because of inadequate health communication and less optimal planning due to patients from various. Health communication must be applied well so that problems do not arise and harm society. The study was conducted on December 16, 2017, to March 26, 2018.

\subsection{Results}

\subsection{Health Communication Services in Aceh}

Several reasons why health communication is necessary are (a) public must obtain good health care, (b) Patients must have their right on health care,(3) The patients feel inferior toward the doctor, and medical personnel, (4) Conflict caused by unequal communication and interaction between patients, hospitals dan doctors that creates conflict, (5) Health quality implies the 'happiness' of society, (6) Professional ethics and the responsibility of proposed four concepts related to participatory communication.

Some forms of poor health communication in health services in Banda Aceh are (1)Poor health management and chronic health problems in Aceh. (2) Service system management cannot provide optimal service. (3) Unbalanced between health facilities and the number of patients. (4) Complicated regulations sometimes make health problems more and more chaotic. (5) The system applied in hospital unequal treatment of patients with different background and status. (6) Complains sometimes come from 'insiders'/employees. (7) The spirit of public services has not been good. (8) The lack of professionalism in health services (hospitals and workers). (9)Standard operational procedures(SOP) are not fully applied. And (10) Attitudes and communication patterns between doctor-patient sometimes also do not work well.

Health communication is still participatory, and there is no openness from the hospital management in providing information, especially to the public, especially patients. This openness and availability of information is a necessity for the wider community. It has become one of the factors creating equal health communication. The result can provide comfort for the community, especially the patient's family. The government and hospital management should provide well-planned policies and communication mechanisms, so that the relationship between doctors, medical personnel and the community becomes transparent, trusted, and contented. Patients need a sense of content and trust in doctors and medical personnel. This is one of the biggest reasons affecting the patient's recovery.

The imperfect conditions of health services are often accomplished with special illness with the biggest hospitals in Banda Aceh because of poor management planning and management. The fragile management of hospitals results in the form of health services for the community. Management of health services is aimed at improving the governance of the service system to provide optimal service. An integrated service system can be respected if all components have the disadvantage that excellent health services are the main acceptance of the community and whatever their background.

Some forms of poor health communication in health services in Banda Aceh are: (1) Poor health management and chronic health problems in Aceh, (2) Service system management cannot provide optimal service, (3) Unbalanced between health facilities and the number of patients, (4) Complicated regulations sometimes make health problems more and more chaotic, (5) The system applied in hospital unequal treatment of patients with different background and status,(6) Complains sometimes come from 'insiders'/employees, (6) The spirit of public services has not been good, (7) The lack of professionalism of health services (hospitals and workers), (8) 
Standard operational procedures (SOP) are not fully applied (SOP) is not fully applied, (9) Attitudes and communication patterns between doctor-patient sometimes also do not work well, and (10) hospital sometimes are not discussed previously with the patient's family before health treatment. Social conditions and government policies are needed in improving public services in the health sector. The government must be able to guarantee that they have political authority to act, issue proper policies and ensure that the implementation of these policies is carried out properly, whatever the challenges that arise. Public health professionals need to understand the political dimensions of the problem and proposed solutions, whether they hold positions in government, advocacy groups, research organizations, or the health care industry. This understanding can help leaders anticipate well both short-term constraints and long-term opportunities for change.

A good policy does not guarantee the quality of health increases but instead requires synergy with various stakeholders involved in health services. One strategy that can maximize energy systems, programs and implementation as a form of policy is communication. Communication has a substantial role in public health and encourages health professionals around the world to utilize communication skills whenever possible. Health researchers and practitioners agree that health communication is an approach that refers to various scientific disciplines, including mass communication, social marketing, health education, anthropology, and sociology (Bernhardt, 2004; Institute of Medicine, 2003; World Health Organization, 2003 in Schiavo, 2007).

\subsection{Health Communication Components-Model}

Health communication with patients include information relating to individual health conditions, information about how to maximize care and how to provide therapy. Health communication in patients/sufferers is more therapeutic, which means that it facilitates the healing process. According to (Purwanto in Damaiyanti, 2008) the purpose of heart communication is: (1) Helping patients reduce the burden of feelings and thoughts and helping patients take action to change the situation when needed by patients, and (2) Helping to reduce patient doubt and help patients take effective action.

This therapeutic health communication can be provided by family, medical experts and people around the patient by considering several principles in therapeutic communication itself, such as (1) therapeutic communication must be characterized by mutual acceptance, mutual trust, and mutual respect. (2) Families, medical experts and people around individuals must be aware of the physical and mental needs of the patient, and (3) understanding the true meaning of empathy as therapeutic action. The process of health communication is clear and understood by all parties who are part of the health administration in Aceh. Therefore we need a health communication model that supports the improvement and improvement of health services to the community. The Aceh Government's political-health communication model for the future development of health services according to the researchers as designed below:

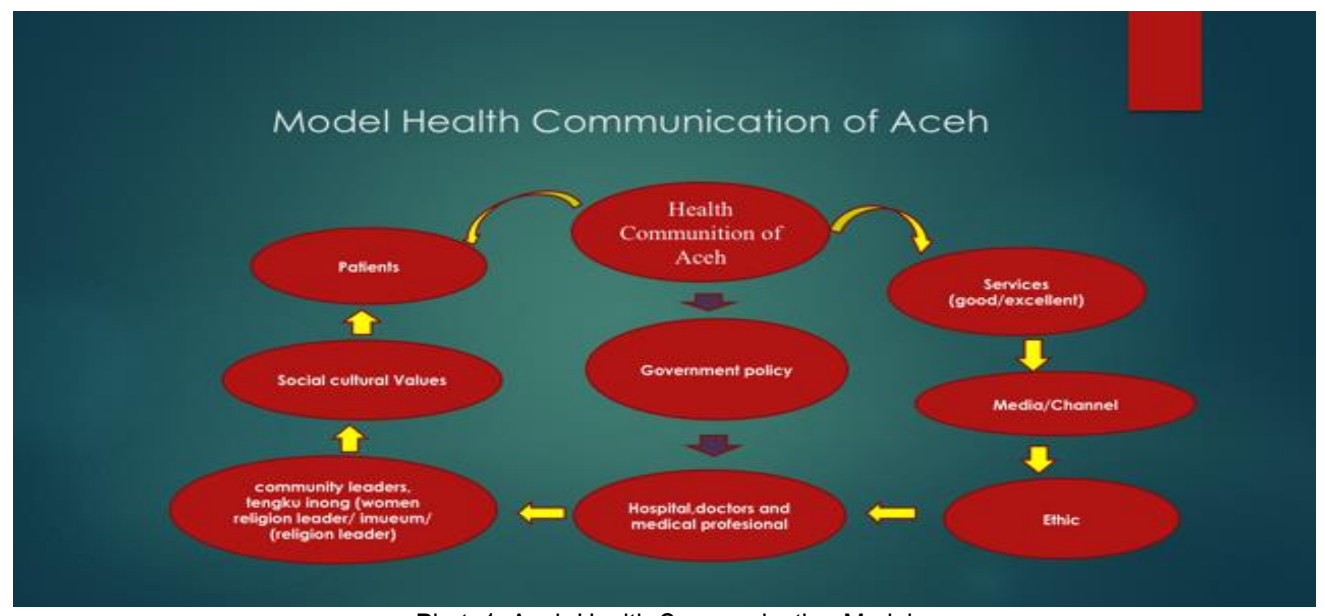

Photo1: Aceh Health Communication Model

Designed by Researchers Based on Theories, Concepts and Research Data

The government, as the holder of authority in the political system and structure, must make policies that can achieve better health care efforts in Aceh. Hospitals, doctors and media institutions are required to provide good and humane services for all patients without exception because the nature of health care is one of the things that need to be recognized by the government. To socialize, the media can use it to facilitate messages from policies taken and understood by the public. For the health service continuity process to reach the target, it requires the involvement of community components such as community leaders, village heads, Teuku nong, NGOs and other general public. All this must be done with clear rules and ethical considerations and with an emphasis on human values. Communication is the process of delivering a message by the communicator to the communicant (Berlo, 1960).

Health communication includes the application of communication services to convey messages and influence the decision-making process related to efforts to improve and manage health by individuals and communities. Besides, health communication also involves the dissemination of information about health to the community to achieve healthy living behaviors, create awareness, change attitudes and motivate individuals to adopt healthy behaviors that are recommended as the primary goal of health communication. (Rahmadiana, 2012) Communication is the process of stimulating operations in the form of symbols or symbols of language or motion 
(nonverbal), to influence the behavior of others. According to Liliweri (2008), communication can be interpreted as a change in message from one source to the recipient so that it can be understood. The communication process usually involves two parties, both between individuals and individuals, individuals with groups or between groups with groups that interact with mutually agreed rules. Communication functions such as: (1) To convey messages (information) or disseminate information to others. That is, from the dissemination of this information expected recipients of information will know what you want to know. (2) To convey messages (information) or spread information that is educational in nature to others. That is, from the dissemination of this information expected recipients of information will increase knowledge about something you want to know. (3) To give instructions to the recipient of the message. And (4) To influence and change the attitude of the recipient of the message.

\subsection{Discussion}

Health communication is required to increase individual awareness and increase individual awareness to get the right health services needed because it encourages them to have a mindset and critical attitude towards the forms of services they do from the hospital. Critical attitudes and behaviors are expected to create a dynamic situation in the service and jump over home management. Patients become active and health workers and hospital operational personnel will act more cautiously. This is necessary for a good and proper system and clear and firm SOPs. Patient satisfaction standards in health services are determined by the Ministry of Health. According to the Regulation of the Minister of Health of the Republic of Indonesia in 2016 concerning Minimum Service Standards for patient satisfaction is above $95 \%$. If health services with a level of patient satisfaction are below $95 \%$, then the health services provided do not meet the minimum standards or do not meet the requirements (Ministry of Health of Indonesia, 2017).

However, in practice, there are still services that are not following hospital service standards and nursing standards. It can be seen from cases involving nursing staff such as lack of patient satisfaction with nursing services because it is considered that nursing services provided are not appropriate in handling patients. Nurses must maintain high-quality nursing services professionally in applying nursing knowledge and skills supporting patient needs (Siswati, 2015). Good communication avoids communication distortions; this creates new problems in community services. Health communication becomes very important in health care because the quality of health care is determined by the communication skills of hospitals, doctors and medical personnel. The quality of communication is not only built together but also by one party. All parties must participate in providing the best health services, such as communication between managers and doctors, medical personnel and patients. The main thing is to create a good relationship between doctors, medical personnel and patients, and their families (Andika dan Astuti, 2018).

The health service process has different perspectives between communicators (hospitals, doctors and health workers) and communicants (patients and the community). Communication behavior will be different if a community has a different background, condition, and language. This happens to a certain extent and context, this error is caused by community understanding and communication behavior during the health service process in Aceh. Communication can be conveyed well through communication patterns that can be understood by the community. The communication strategy adjustments are arranged and designed with information that is easily understood so that the public can receive messages.

The purpose of this communication is transactional communication through the sender and recipient of the message so that the community or individuals involved reach the suitability of the message. The term dialogue refers to the involvement of communicators and communicants, this process will open many opportunities to exchange ideas in solving certain problems. However, this has not been widely applied to increase awareness of health services in hospitals, so that the flow of communication runs poorly and does not increase public satisfaction. The process of health communication between the hospital doctor and medical staff must establish the ideal of participatory communication. This affects the various components of the communicator and the involvement of the communicant in it. This mechanism is expected to create and form interdependent bonding relationships with each other. Community service cannot be done by one party alone, especially for the government. This must be done simultaneously so that the dynamics of good and strong health communication are created.

There are several components of health communication such as (1) communicator, (2) message, (3) Media/Network/channel, (4) Communicant/Audience, (5) Effect, (6) Response, and (7) Feedback. Health communication must be applied based on the socio-cultural values of the communities where services and hospitals are domiciled. Cultural values become a strong force in community empowerment in the process of implementing health communication. The closeness and understanding of the community with cultural values will facilitate the recruitment of the models and systems that are applied. Health Communication Based on social culture that must be carried out by the Government of Aceh are (1) the Government of Aceh must make policies that support the community to get good health services, (2) One of the most urgent is the use of health communication to improve health services by hospitals, doctors and other media personnel, (3) Creating Aceh as the region with the best health services, (4) The government is conducting a campaign on the importance of health communication, and (5) Aceh The government can utilize Gampong shareholders to build public awareness about health and healthy living. Health communication must be applied based on the socio-cultural values of the communities where services and hospitals are domiciled. Cultural values become a strong force in community empowerment in the process of implementing health communication. The closeness and understanding of the community with cultural values will facilitate the recruitment of the models and systems that are applied.

Various findings, studies, and science can identify solutions to suppress and provide alternative solutions to public health problems, but those are meaningless if there is no support from the government. Government policies on strategies and programs to improve the quality of health services have proven to have a greater influence on the changes that are taking place. The power and authority that the 
government has can legalize various forms of rules that defend the interests of the general public. This means that in this context, only politics can turn most of these solutions into reality. Analysis of the problem is needed, but politics is more than analyzing in determining policy. it means that policies are governed by various ways in which people exercise control, influence, or power over one another (104) (in Oliver, 2006).

Many chronic disease disorders are caused by the inability of individuals to lead healthy lives and the inability of individuals to take responsibility for their health status because they have been immersed in an unhealthy lifestyle. For the health communication strategy to reach the target, government policy is needed. Government power and authority are believed to be able to accelerate the implementation of health communication needs and can reach all levels of society equally. Government policies that give birth to regulations in the field of health services are needed so that health services as a right of every citizen can be fulfilled properly regardless of negligence. Therefore, politics in the field of health communication makes it easy for health programs to reach the public openly, on a par with every citizen.

\subsection{Conclusion}

Determination of motion and form of processes and social interactions is communication. Communication is "blood or energy" for social systems. Communication can build the reality of community groups or community groups to reflect all activities consciously in various forms through the processes and forms of communication that take place. A communication process is a form of exchange of meaning and means in the delivery of attitudes or thoughts. The communication process is where communicators and communicants communicate with each other. Communication can be either reciprocal or one-way communication. One of the bad services for the community is caused by the poor quality of communication. Good and effective communication will create models, systems, and behavior in public health services. Starting from health communication strategies, processes, activities, packaging messages, using the media, people who are afraid and the independence of the community to express their complaints or experiences that are not following what they experienced. Good health communication will create a satisfied community because it will create independence and quality of dialogue between the parties.

Therefore, health communication is needed to improve health services by the government. For some reason, health communication is needed to improve health services in government hospitals such as the Zainal Abidin Hospital in Banda Aceh. One solution that can be done is to build a participatory health communication model and system through the use of communication technology, especially social media. Health communication is needed to increase individual awareness about health problems, health risks, and health solutions. Increased awareness of individuals is needed to get appropriate health services because it encourages them to have a mindset and critical attitude towards the forms of service they receive from the hospital. Critical attitudes and behaviors are expected to create a dynamic situation in the service and jump over home management. Patients become active and health workers and hospital operational personnel will act more cautiously. this requires a good and precise system and clear and firm SOPs.

Applying appropriate health communication is very important so patients feel comfortable and trust the care process they receive. Patient comfort and trust can grow because health communication is believed to be the reason patients recover faster. Therefore, the health communication model in government hospitals is needed to manage communication in the application of health. Patients as ordinary people need good interaction and care for health services. In this effort, political power plays an important role because it can make policies contained in the rules regarding the guarantee of quality health services for every citizen without exception.

\section{Acknowledgements}

Appreciation and gratitude to those who have supported this research and publication, that is; 1). Budi Luhur University and Budi Luhur Cakti Foundation. 2). The Ministry of State Secretariat (Setneg RI) through the Bureau of Press, Media, and Information 3). All Key Informants and Informants Research.

\section{References}

Andika, F. (2018). Analisis Faktor Kepuasan Pasien BPJS JKRA dengan Kinerja Perawat di Rawat Inap Rumah Sakit Umum Daerah Meuraxa Kota Banda Aceh. JOURNAL OF HEALTHCARE TECHNOLOGY AND MEDICINE, 4(2), 207-217.

Cheng, J. W., Mitomo, H., Otsuka, T., \& Jeon, S. Y. (2015). The effects of ICT and mass media in

post-disaster recovery-a two model case study of the Great East Japan Earthquake. Telecommunications Policy, 39(6), 515-532.

Dennis, M. (2012). Mass Communication Theori, Sage Publication, New York

Fajri, R. (2017, June 9). Banyak Masalah, Ombudsman Kaji Pelayanan Kesehatan di Aceh Barat.

https://www.ajnn.net/news/banyak-masalah-ombudsman-kaji-pelayanan-kesehatan-di-aceh-barat/index.html

Kim, H., Sefcik, J. S., \& Bradway, C. (2017). Characteristics of qualitative descriptive studies: A systematic review. Research in nursing \& health, $40(1), 23-42$.

Kusumadinata, A. A., Sarwoprasodjo, S., \& Purnaningsih, N. (2012). Analisis Komunikasi Partisipasi dalam Penyelenggaraan Program Perbaikan Gizi Masyarakat (Studi Kasus pada Kelompok Gizi Masyarakat Pulokerto Kota Palembang). Jurnal Komunikasi Pembangunan, 10(2).

Littlejohn, S. W., \& Foss, K. A. (2009). Theories of Human Communication. Thomson: Wadsworth 
Lukiati, K., Hafiar, H., Damayanti, T., Puspitasari L. (2014). Implementasi Model Komunikasi Kesehatan Two Step Flow Communication dalam Menyebarkan Informasi Kesehatan Ibu dan Janin melalui Para Dukun Beranak di Jawa Barat. KAREBA: Jurnal IImu Komunikasi, 3(1), 38-50.

Lederman, L. C., Kreps, G. L., \& Roberto, A. J. (2017). Health communication in everyday life.

Rahmadiana, M. (2012). Komunikasi kesehatan: sebuah tinjauan. Jurnal Psikogenesis, 1(1), 88-94.

Ulya, F. N. (2019, August 19). Kendala Ini Membuat Pelayanan Kesehatan di Indonesia. https://sains.kompas.com.

Moleong, L. J. (2012). Metodologi Penelitian Kualitatif, Edisi Revisi Cet. Ketigapuluh. Bandung: Remaja Rosdakarya Bandung

Mulyana, Deddy. (2016), The Health and Therapeutic Communication Book: An Intercultural Perspective. Bandung, Penerbit Rosda Karya.

.........., (2016), Pengantar Ilmu Komunikasi, Rosdakarya, Bandung

Nasdian, F. T. (2006). Pengembangan Masyarakat (Community Development). Bogor: Bagian Sosiologi Pedesaan dan Pengembangan Masyarakat Departemen Komunikasi dan Pengembangan Masyarakat Institut Pertanian Bogor.

Prilutski, M. A. (2010). A brief look at effective health communication strategies in Ghana. Elon J Undergrad Res Commun, 1,51-58.

Oliver, T. R. (2006). The politics of public health policy. Annu. Rev. Public Health, 27, 195-233.

Rakhmat, J. (2009). Psikologi komunikasi (cetakan keduapuluh tujuh). Bandung: Remaja Rosdakarya.

Salisah, N. H. (2011). Komunikasi Kesehatan: Perlunya Multidisipliner dalam IImu Komunikasi. Jurnal IImu Komunikasi, 1(2), 170-192.

Schiavo, R. (2013). Health communication: From theory to practice (Vol. 217). John Wiley \& Sons.

Sugiyono, P. (2015). Metode penelitian kombinasi (mixed methods). Bandung: Alfabeta.

Waisbord, S. (2014). The strategic politics of participatory communication. The handbook of development communication and social change, $145-167$.

Warsita, B. (2008). Teknologi pembelajaran landasan dan aplikasinya. Jakarta: Rineka Cipta, 135.

Wood, J. T. (2000). Communication theories in action: An introduction. Wadsworth Publishing Company.

Yahya, S. M., Wardiati, W., \& Anwar, S. (2016). Tingkat Pelayanan Terhadap Pasien Peserta Jaminan Kesehatan Aceh di Ruang Rawat Inap Rumah Sakit Umum Meuraxa Banda Aceh. Jukema (Jurnal Kesehatan Masyarakat Aceh), 2(1) 